\title{
SIKAP DAN MOTIVASI PETANI TANAMAN PADI TERHADAP ADOPSI PROGRAM KARTU TANI DI KABUPATEN GROBOGAN
}

\section{(ATTITUDES AND MOTIVATION OF RICE FARMERS ON ADOPTION FARMER CARD PROGRAMS (PROGRAM KARTU TANI) IN GROBOGAN REGENCY)}

\author{
Meliyanawati, Wulan Sumekar, Tutik Dalmiyatun \\ Program Studi S1 Agribisnis Fakultas Peternakan dan Pertanian Universitas Diponegoro, Jl. Prof \\ Sudarto no.13, Tembalang, Semarang, Indonesia \\ Email: Meliyanawati2694@gmail.com
}

Diterima 4 November 2019, disetujui 23 Mei 2020

\begin{abstract}
ABSTRAK
Kebijakan subsidi pupuk merupakan upaya yang dilakukan pemerintah untuk mengatasi permasalahan ketersediaan dan distribusi pupuk yang tidak merata, akan tetapi adanya kartu tani masih mengalami pro dan kontra di kalangan petani. Penelitian telah dilaksanakan di Kabupaten Grobogan pada tanggal 12 Februari 2019 sampai tanggal 5 Maret 2019. Tujuan penelitian adalah untuk menganalisis sikap, motivasi, adopsi dan pengaruh sikap dan motivasi terhadap adopsi program kartu tani. Metode penelitian yang digunakan dalam penelitian ini adalah metode survei. Populasi yang digunakan dalam penelitian ini adalah petani tanaman padi anggota kelompok tani berprestasi di Kabupaten Grobogan (Kelompok tani Maju, Kelompok tani Margo Husodo, Kelompok tani Karya Mukti). Sampel penelitian ditentukan secara acak dengan jumlah 86 responden diperoleh dari rumus Slovin. Pengumpulan data dilakukan menggunakan metode wawancara dan observasi secara langsung. Data kemudian dianalisis menggunakan uji regresi linear berganda. Hasil penelitian menunjukkan karakteristik responden didominasi oleh laki-laki berusia produktif yang memiliki pengalaman bertani cukup lama, tetapi memiliki tingkat pendidikan yang relatif rendah. Sikap, motivasi dan adopsi petani terhadap kartu tani berturut-turut tergolong sedang. Faktor sikap dan motivasi berpengaruh terhadap adopsi. Variabel sikap dan motivasi mempengaruhi variabel adopsi sebesar $79,4 \%$ dan sisanya dipengaruhi oleh variabel lain. Variabel sikap dan motivasi memiliki pengaruh sangat nyata terhadap variabel adopsi $(\operatorname{sig}<0,05)$
\end{abstract}

Kata kunci : adopsi, kartu tani, motivasi, sikap, regresi linear berganda

ABSTRACT

Fertilizer subsidy policy is an effort made by the government to provide facilities to farmers. Based on evaluation of availability and distribution of fertilizers, the government created a farmer card program (program kartu tani) in hopes of overcoming fertilizer problembs, but the axistence of farmer card program still a pro and a contra among farmers. This research was conducted in Grobogan Regency on 12 February 2019 to 5 march 2019. the purpose of this research was to analyze the attitude, motivations, adoption and the effect of rice farmers attitudes and motivations on adoption of farmer card program (program kartu tani). The methods used in this research was survey method. The population used in this research is rice farmers who are members of the outstanding farmers group in Grobogan Regency (Maju farmers group, Margo Husodo farmers group, Karya Mukti farmers group). Research samples was determined randomly with a tota; of 86 respondents obtained from the slovin formula. Data collection is done using interviews and direct observation. Data were analyzed using 
multiple linear regression test. The result of the research showed that respondents characteristics were dominated by male farmers who were still in productive age who had a long farming experience, but had a relatively low education level. Farmers attitudes, motivations and adoptions of the farmer card program were classified as medium. Attitude and motivation factors affect adoption. Attitude and motivation variables affect the adoption variable 70,4\%. Attitude and motivation variables have a very real influence on the adoption variable.

Keywords: Adoption, attitude, farmer card, multiple linear regression test, motivation

\section{PENDAHULUAN}

Indonesia termasuk salah satu negara dengan iklim tropis yang sesuai ditanami berbagai macam tanaman serta memiliki potensi sumber daya alam yang cukup tinggi. Keadaan ini menjadikan Indonesia sebagai negara agraris dimana sektor pertanian memiliki peran yang penting bagi negara diantaranya yaitu penyedia bahan pangan, pakan dan bahan baku, sebagai penyerap tenaga kerja terbesar periode 2011-2016 menurut Badan Pusat Statistik Republik Indonesia tahun 2018 yaitu 38,73 juta tenaga kerja, penyedia Produk Domemstik Bruto (PDB) dan sumber pendapatan rumah tangga pedesaan yang utama (Haris et al, 2017). Subsektor tanaman pangan termasuk penting dalam sektor pertanian, hal ini karena subsektor tanaman pangan menjadi target utama dalam pembangunan Indonesia periode 2014 sampai 2019 untuk penguatan pangan dan diversifikasi konsumsi pangan dengan meningkatkan ketersediaan pangan dari dalam negeri untuk komoditas padi, jagung dan kedelai (Wijaya, 2017).

Program penguatan pangan terkait dengan jumlah penduduk Indonesia yang semakin meningkat, sehingga memerlukan pangan yang cukup besar. Prediksi jumlah penduduk di Indonesia pada tahun 2030 akan mencapai 350 juta jiwa dan kebutuhan beras akan meningkat hingga 90 sampai 100 juta ton per tahun (Badan Pusat Statistik Republik Indonesia, 2016). Pemerintah menjadikan padi sebagai salah satu komoditas tanaman pangan yang diutamakan peningkatan produksinya. Hal ini bertujuan agar Indonesia mampu mencapai tingkat swasembada sehingga dapat mengurangi resiko kurangnya suplai pangan di Indonesia. Keberlangsungan peningkatan sektor tanaman pangan ini tidak lepas dari faktor-faktor produksi yang digunakan, diantaranya yaitu benih, pestisida dan pupuk. Kebutuhan petani akan pupuk yang semakin meningkat, ketersediaan pupuk di pasaran justru semakin tidak menentu. Hal ini disebabkan karena tidak meratanya distribusi pupuk bersubsidi di tiap wilayah. Sebagai upaya mengatasi permasalahan ketidakmerataan distribusi pupuk bersubsidi, pemerintah Provinsi Jawa Tengah membuat program kartu tani agar dapat memenuhi asas 6 Tepat (tepat jumlah, jenis, waktu, tempat, mutu, dan harga).

Program kartu tani merupakan program yang baru diberlakukan di provinsi Jawa Tengah. Salah satu daerah yang menerima kartu tani yaitu Kabupaten Grobogan sebagai daerah yang memiliki jumlah petani tanaman pangan terbanyak di jawa tengah yaitu 228.751 petani. Hingga akhir juli 2017, tercatat $92,13 \%$ petani di jawa tengah telah menerima serta menggunakan kartu tani dan masih akan berlanjut hingga kartu tani dapat mencapai seluruh petani di Jawa Tengah dan juga diharapkan dapat diterapkan di seluruh Indonesia (Badan Pusat Statistik Provinsi Jawa Tengah, 2018).

Program yang dibuat pemerintah akan dapat diterapkan dan terlaksana dengan baik apabila program tersebut dapat mencapai dan diterima oleh sasaran program. Putra et al (2012) menyatakan bahwa penerimaan tersebut dapat dipengaruhi oleh beberapa faktor diantaranya yaitu motivasi, sikap, serta partisipasi petani dalam kegiatan sosialisasi, penyuluhan dan pelatihan. Oleh karena itu penelitian ini perlu dilakukan untuk menganalisis bagaimana pegaruh sikap dan motivasi petani padi terhadap adopsi program kartu tani di Kabupaten Grobogan. 


\section{METODE PENELITIAN}

Penelitian dilaksanakan pada Bulan Februari 2019 - Maret 2019 di Kabupaten Grobogan. Lokasi penelitian dipilih dengan metode purposive karena Kabupaten Grobogan merupakan Kabupaten yang memiliki jumlah petani tanaman pangan terbanyak di Jawa Tengah.

Metode yang digunakan adalah metode survey. Pemilihan sampel dilakukan secara purposive sampling dengan kriteria responden merupakan petani anggota kelompok tani berprestasi di Kabupaten Grobogan.

Metode yang digunakan adalah metode survey. Pemilihan sampel dilakukan secara purposive sampling dengan kriteria responden merupakan petani anggota kelompok tani berprestasi di Kabupaten Grobogan. Pengambilan sampel dilakukan pada tiga kelompok tani berprestasi yang telah mendapat juara tingkat nasional di bidang tanaman pangan dari 1.678 kelompok tani yang ada di Kabupaten Grobogan (Kabupaten Grobogan Dalam Angka, 2018). Diketahui kelompok tani tersebut adalah kelompok tani Margo husodo, Desa Tarub, Kecamatan Tawang Harjo (249 orang). Kelompok tani Karya Mukti (179 orang), Desa Karang Rejo (166 orang), Kecamatan Grobogan dan kelompok tani Maju, Desa Winong, Kecamatan Panawangan. Total anggota ketiga kelompok tani tersebut adalah 549 orang. Sampel ditentukan menggunakan pendekatan rumus Slovin sehingga diperoleh sebanyak 86 orang responden, kemudian digunakan metode alokasi proporsional untuk mengetahui banyaknya petani yang dijadikan sampel dari tiap kelompok tani. Adapun perhitungannya adalah sebagai berikut:

Jumlah anggota Kelompok Tani Margo Husodo $=249$ orang

Jumlah anggota Kelompok Tani Karya Mukti $=179$ orang

Jumlah anggota Kelompok Tani Maju

$=166$ orang

Total $=549$ orang

Rumus Slovin, $n=\frac{\mathrm{N}}{\mathrm{n}\left(\mathrm{e}^{2}\right)+1} \quad$ (Riyanto dan
Hatmawan, 2020)

$\mathrm{n}=$ ukuran sampel

$\mathrm{N}=$ ukuran populasi

$\mathrm{e}=$ error margin $(10 \%)$

$\mathrm{n}=\frac{594}{594\left(0,1^{2}\right)+1}=86$ orang

rumus proporsional, $\mathrm{n}_{\mathrm{i}}$

$=\left[\frac{\mathrm{N}}{\mathrm{N}_{\mathrm{i}}}\right] \mathrm{n}$ (Sugiyono, 2015)

$\mathrm{n}_{\mathrm{i}}=$ unit sampel / kelompok tani

$\mathrm{N}=$ populasi pada masing-masing kelompok $\mathrm{t}$ ani

$\mathrm{N}_{\mathrm{i}}=$ total populasi

$\mathrm{n}=$ total sampel

$$
\begin{array}{ccc}
\begin{array}{c}
\text { Margo } \\
\text { Husodo }
\end{array} & \begin{array}{c}
\text { Karya } \\
\text { Mukti }
\end{array} & \text { Maju } \\
\frac{249}{594} \times 86=36 & \frac{179}{594} \times 86=26 & \frac{166}{594} \times 86=24
\end{array}
$$

Data primer diperoleh dari metode wawancara disertai kuisioner dan data sekunder diperoleh dengan pencatatan data yang ada di instansi terkait. Metode analisis data yang akan digunakan dalam penelitian ini adalah uji regresi linear berganda. persamaan Regresi dalam penelitian ini adalah untuk mengetahui seberapa besar pengaruh variabel bebas yaitu Sikap (X1) dan Motivasi (X2), terhadap Program Kartu Tani (Y). Rumus matemastis dari regresi berganda yang akan digunakan dalam penelitian ini adalah :

$$
\mathbf{Y}=\mathbf{a}+\mathbf{b} 1 \mathrm{X} 1+\mathrm{b} 2 \mathrm{X} 2+\mathrm{e}
$$

$\mathbf{X 1}=$ Sikap

X2 = Motivasi

$\mathbf{Y}=$ Program Kartu Tani

a $=$ Konstanta

b1 = Koefisien regresi antara Sikap dengan Program Kartu Tani

b2 $=$ Koefisien regresi antara Motivasi dengan Program Kartu Tani 


\section{HASIL DAN PEMBAHASAN}

\section{Karakteristik Responden}

Berdasarkan penelitian, dilakukan identifikasi karakteristik responden yang meliputi jenis kelamin, umur, pendidikan, lama bertani dan luas lahan. Detail informasi karakteristik responden dapat dilihat sebagai berikut :

Berdasarkan Tabel 1, diketahui bahwa dari 86 orang petani tanaman padi yang menjadi responden, $96,5 \%$ nya adalah petani laki-laki yaitu sebanyak 83 orang. Hal ini menunjukkan bahwa kegiatan pertanian tanaman pangan didominasi oleh petani berjenis kelamin pria. Keadaan ini disebabkan karena adanya pengaruh lingkungan sosial budaya di Kabupaten Grobogan yang masih meyakini paham patriarki. Hal ini sesuai dengan pendapat Sakina dan Siti (2017) yang menyatakan bahwa budaya patriarki merupakan keadaan dimana pria memiliki peran yang mendominasi dalam kegiatan bermasyarakat sedangkan wanita tidak memiliki peran atau pengaruh dalam masyarakat.

Pria sebagai kepala keluarga juga merupakan perwakilan keluarga dalam berbagai kegiatan juga merupakan salah satu penyebab banyaknya anggota kelompok tani berjenis kelamin pria dibanding wanita. kegiatan yang berkaitan dengan menyumbang pendapatan keluarga kususnya dibidang pertanian dalam pelaksanaannya membutuhkan tenaga yang besar, sehingga lebih identik dengan pria dari pada wanita dalam kegiatan pertanian. Hal ini sesuai dengan pendapat Rahmawati dan Sunito (2013) yang menyatakan bahwa pembagian kerja dalam keluarga atau masyarakat, salah satunya dapat dilihat dari waktu dan tempat melaksanakan kegiatan produktif atau kegiatan yang dapat membantu menghasilkan pendapatan keluarga baik dari segi keuangan

Tabel 1. Karakteristik Petani Padi di Kabupaten Grobogan

\begin{tabular}{lcr}
\hline Karakteristik Responden & $\begin{array}{c}\text { Jumlah Petani } \\
\text { (Orang) }\end{array}$ & $\begin{array}{c}\text { Persentase } \\
(\%)\end{array}$ \\
\hline Jenis Kelamin & 83 & 96,5 \\
Pria & 3 & 3,5 \\
Wanita & & \\
Umur & 18 & 21 \\
$32-42$ & 38 & 44,1 \\
$43-53$ & 16 & 18,6 \\
$54-64$ & 14 & 16,3 \\
$>64$ & & \\
Pendidikan & 11 & 13 \\
Tidak sekolah & 56 & 65 \\
SD & 13 & 15 \\
SMP & 6 & 7 \\
SMA & & \\
Lama Bertani & 7 & 8,1 \\
$1-10$ & 31 & 36,1 \\
$11-20$ & 32 & 37,2 \\
$21-30$ & 16 & 18,6 \\
$31-40$ & & 90 \\
Luas Lahan & 77 & 8 \\
$0-1$ & 7 & 2 \\
$>1-2$ & 2 & \\
$>2$ & & \\
\hline Sumber: Data Primer Pen & & \\
\hline
\end{tabular}

Sumber: Data Primer Penelitian, 2018 
maupun barang, salah satunya adalah kegiatan dalam bidang pertanian. Bidang ini didominasi oleh pria karena pria identik dengan tenaga yang lebih mumpuni untuk kegiatan fisik seperti pengolahan lahan hingga pemanenan dan pemasaran serta lebih memungkinkan untuk bergabung dalam kelompok kemasyarakatan di bidang pertanian.

Responden petani tanaman padi di Kabupaten Grobogan rata-rata berumur 43-53 tahun, berjumlah 38 orang dengan persentase $44,1 \%$. Hal tersebut menunjukkan rata-rata responden masih berada dalam usia produktif. Hal ini sesuai dengan Undang-Undang No.13 Tahun 2003 yang menyebutkan bahwa tenaga kerja produktif adalah yang berumur antara 15 sampai 64 tahun. Petani yang berada dalam usia produktif akan mampu mengelola usahataninya dengan baik. Faktor usia petani berkaitan dengan kemampuan petani dari segi fisik dan tenaga yang akan digunakan untuk mengelola usahataninya seperti pengolahan lahan, penanaman, pemupukan hingga panen. Hal ini sesuai dengan pendapat dapat Burhansyah (2014) yang menyatakan bahwa petani yang berada dalam usia produktif dapat diandalkan untuk mengembangkan usahatani padi dengan baik, serta berpeluang untuk terus meningkatkan usahataninya karena didukung sumberdaya manusia produktif.

Petani yang berada dalam usia produktif juga akan lebih mudah untuk melakukan adopsi terhadap inovasi terkait usaha taninya. Hal ini dikarenakan petani dalam usia produktif memiliki kapasitas yang lebih baik untuk menerima informasi terkait inovasi yang baru diketahuinya. Hal ini sesuai dengan pendapat Moko (2017) yang menyatakan bahwa faktor umur memiliki pengaruh terhadap petani dalam menerima informasi baru dan lebih terbuka serta memiliki kemauan untuk menerima suatu inovasi.

Pendidikan responden paling banyak pada tingkat SD, yaitu 56 orang dengan persentase $65 \%$. dan tingkat pendidikan paling sedikit adalah SMA yaitu sebanyak 6 orang dengan persentase $6 \%$. Banyaknya petani yang memiliki tingkat pendidikan menengah kebawah menunjukkan tingkat pendidikan petani yang relatif rendah. Hal ini disebabkan karena untuk mengelola lahan pertanian dibutuhkan keterampilan terapan, sehingga petani padi di Kabupaten Grobogan lebih mengutamakan keterampilan terapan dibandingkan dengan pendidikan formal. Tingkat pendidikan petani akan mempengaruhi cepat atau lambatnya pemahaman seseorang dalam menerima halhal baru atau inovasi baru. Menurut Fachrista dan Sarwendah (2014) dalam penelitiannya menunjukkan bahwa tingkat pendidikan berpengaruh secara nyata terhadap adopsi. Pendidikan petani yang tinggi akan membuat petani menjadi lebih mudah untuk menerima dan menerapkan teknologi baru.

Pengalaman lama bertani responden ratarata selama 11-30 tahun. Hal tersebut menunjukkan bahwa petani padi di Kabupaten Grobogan telah memiliki pengalaman bertani yang cukup lama dan turun-temurun. Pengalaman bertani yang dimiliki petani akan mempengaruhi petani dalam mengambil keputusan terhadap suatu program. Hal tersebut disebabkan karena petani yang memiliki pengalaman bertani cukup lama akan memiliki keterampilan serta pengetahuan yang lebih baik.

Keterampilan dan pengetahuan yang dimiliki petani dari penglaman bertaninya akan membuat petani mampu mempertimbangkan dengan baik mengenai inovasi yang belum pernah dicoba selama menjalankan usaha pertaniannya. Pertimbangan yang dilakukan petani dari pengalaman bertaninya akan menimbulkan keinginan untuk dapat berkembang dan meningkatkan aspek-aspek terkait usahataninya. Hal ini sesuai dengan pendapat Hariyani (2013) yang menyatakan bahwa pengalaman lamanya bertani akan mempengaruhi keputusan petani terhadap suatu inovasi, pengalaman tersebut dapat dijadikan pembelajaran untuk menambah pengetahuan dan mencoba inovasi baru yang belum pernah diterapkan oleh petani.

Responden paling banyak memiliki lahan 0 sampai 1 Ha yaitu sebanyak 77 orang 
dengan persentase $90 \%$. Hal tersebut menunjukkan bahwa rata-rata responden memiliki lahan 0 sampai $1 \mathrm{Ha}$. Luas lahan yang dimiliki petani padi di Kabupate Grobogan terbilang cukup sempit, karena rata-rata kurang dari $1 \mathrm{Ha}$. Hal ini sesuai dengan pendapat Nirzalin (2017) yang menyatakan bahwa mayoritas petani di indonesia adalah petani gurem karena lahan yang dimiliki serta penggunaan lahan petani relatif kecil dengan luas sekitar kurang dari 1 Ha.

Luas lahan yang dimiliki petani memiliki keterkaitan dengan kebutuhan pupuk. Apabila lahan sempit maka kebutuhan pupuk relatif lebih sedikit, begitu pula sebaliknya. Sempitnya lahan pertanian yang dimiliki petani padi di Kabupaten Grobogan dikarenakan banyaknya alih fungsi lahan dari lahan pertanian menjadi lahan non pertanian yang terjadi dari tahun ke tahun. Hal ini sesuai dengan pendapat Sunanto (2013) yang menyatakan bahwa luasnya lahan sawah dipengaruhi oleh program pembangunan, khususnya pembangunan sarana perumahan dan ekonomi wilayah setempat.

\section{Analisis Sikap Petani Tanaman Padi terhadap Program Kartu Tani}

Pada pelaksanaan program kartu tani, terdapat beberapa tanggapan dan sikap yang berbeda dari petani. Berdasarkan wawancara terdapat petani yang merasa terbantu dengan program kartu tani, ada juga kontra dari petani karena merasa kesulitan dalam penggunaan kartu tani. Berdasarkan penelitian yang telah dilakukan, diperoleh penggolongan sikap petani sebagai berikut :

Berdasarkan Tabel 2, dapat diketahui bahwa responden terbanyak tergolong sikap sedang yaitu 46 orang dengany persentase $53,5 \%$. Sikap petani yang tergolong sedang dapat ditinjau dari komponen kognitif, afektif dan konatif. Komponen kognitif petani dengan rata-rata nilai 3,03 menunjukkan bahwa petani memiliki pengetahuan yang cukup baik terkait kebijakan kartu tani. Petani mengetahui bahwa kartu tani bertujuan untuk mengatasi masalah pemerataan dari sistem distribusi pupuk baik itu dari segi jumlah, jenis, waktu, tempat, mutu dan harga. Petani juga mengetahui prosedur pembuatan kartu tani dan manfaat kartu tani.

Sikap petani dari komponen afektif, petani merasa bahwa kartu tani sebenarnya bermanfaat untuk kegiatan bertaninya, akan tetapi masih merasa kesulitan dalam menggunakannya, sehingga petani masih dalam proses untuk beradaptasi terhadap teknologi yang baru diketahuinya. Informasi mengenai kartu tani masih sebatas dari penyuluh saja dan petani merasa tidak memiliki cukup waktu untuk mencari tahu informasi terkait kartu tani secara mandiri dari sumber lain secara lebih mendetail. Secara konatif, petani cenderung mau menggunakan kartu tani dan telah mencoba menggunakan kartu tani beberapa kali. Menurut Azwar (2007) adanya konsistensi antara komponen kognitif, afektif dan konatif tersebut maka dapat dijadikan landasan untuk menyimpulkan sikap petani.

Keadaan tersebut menunjukkan bahwa sikap petani di Kabupaten Grobogan dipengaruhi oleh beberapa faktor baik dari segi internal maupun eksternal diantaranya adalah karena petani merasa kartu tani memiliki manfaat untuk kegiatan bertaninya, karena rekan sesama petaninya juga menggunakan kartu tani dan karena adanya

Tabel 2. Jumlah dan Persentase Responden berdasarkan Tingkat Sikap

\begin{tabular}{cccccc}
\hline \multirow{2}{*}{$\begin{array}{c}\text { Kategori } \\
\text { Sikap }\end{array}$} & $\begin{array}{c}\text { Jumlah } \\
\text { Petani } \\
\text { (Orang) }\end{array}$ & Kognitif & Afektif & Konatif & Persentase \\
Rendah & 11 & 1,92 & 1,81 & 2,07 & 12,8 \\
Sedang & 54 & 3,03 & 2,50 & 2,30 & 62,8 \\
Tinggi & 21 & 3,81 & 4 & 4,23 & 24,4 \\
Jumlah & 86 & & & & 100 \\
\hline
\end{tabular}


penyuluhan dan pembinaan dari lembaga terkait. Hal ini sesuai dengan penelitian Ayu et al (2018) yang menyatakan bahwa pembentukan sikap dipengaruhi oleh beberapa faktor yaitu faktor pengalaman pribadi, kebudayaan, orang lain yang dianggap penting, media massa, lembaga pendidikan dan faktor emosi dalam diri individu.

\section{Analisis Motivasi Petani Tanaman Padi terhadap Program Kartu Tani}

Kartu tani digunakan petani untuk penebusan pupuk bersubsidi, petani memiliki motivasi yang beragam pada penggunaan kartu tani. Berdasarkan wawancara, sebagian besar petani termotivasi menggunakan kartu tani karena kebutuhan untuk mendapatkan pupuk bersubsidi. Dikarenakan kebijakan pembelian pupuk bersubsidi hanya bisa ditebus dengan menggunakan kartu tani sehingga mau tidak mau petani harus mau mengikuti kebijakan tersebut. Adapun tingkatan motivasi petani dalam menggunakan kartu tani dapat dilihat pada Tabel 3.

Berdasarkan Tabel tersebut, diketahui bahwa responden rata-rata memiliki tingkat motivasi sedang yaitu sebanyak 59 orang dengan persentase $68,6 \%$. tergolong memiliki tingkat motivasi sedang. Tingkat motivasi sedang disebabkan karena beberapa petani masih merasa kesulitan baik dalam segi akses maupun teknis dalam menggunakan kartu tani. Petani juga merasa walaupun kartu tani memang bermanfaat, tetapi tak ada perbedaan yang signifikan antara menggunakan dan tidak menggunakan kartu tani. Petani merasa lebih termotivasi jika diberikan kemudahan dalam penebusan pupuk menggunakan kartu tani, contohnya adalah dalam bentuk diperbolehkannya penebusan pupuk. Hal ini sesuai dengan pendapat Kurniawati (2018) yang menyatakan bahwa petani akan lebih mudah menerima program kartu tani apabila diberi kemudahan dalam sistem dan teknis pembelian pupuk.

Berdasarkan tabel tersebut, motivasi yang paling besar mendorong Petani padi di Kabupaten Grobogan untuk memakai kartu tani adalah karena motivasi kebutuhan fisik akan pupuk bersubsidi. Petani terdorong menggunakan kartu tani untuk mendapatkan pupuk sebagai salah satu faktor produksi yang dibutuhkan dalam budidaya tanaman padi. Kartu tani dapat menjamin petani untuk mendapatkan pupuk sesuai dengan jumlah, jenis, harga, waktu, mutu dan tempat yang dibutuhkan, sehingga petani mau menggunakan kartu tani. Motivasi terbesar kedua yaitu motivasi sosial, dimana petani merasa bertanggung jawab atas kartu tani yang telah diberikan oleh pemerintah. tanggung jawab ini menjadikan petani saling memperluas relasi dan bekerjasama untuk dapat bersama-sama bisa menggunakan kartu tani, sehingga beberapa petani ingin ikut menggunakan kartu tani karena mengikuti petani lain. motivasi ketiga yang mendorong petani yaitu motivasi ekonomi, dimana petani dapat memperoleh pupuk bersubsidi yang harganya lebih murah sehingga dapat menekan pengeluaran biaya pembelian pupuk.

Motivasi petani dapat ditingkatkan dengan adanya dukungan dan kerjasama dari berbagai pihak seperti lembaga pemerintah, swasta, maupun lembaga masyarakat terkait. Adanya keterlibatan lembaga yang ahli dalam bidangnya dan lingkungan yang mendukung

Tabel 3. Hasil Jumlah dan Persentase Responden berdasarkan Tingkat Motivasi

\begin{tabular}{lcc}
\hline Motivasi & $\begin{array}{c}\text { Jumlah Petani } \\
\text { (Orang) }\end{array}$ & $\begin{array}{c}\text { Persentase } \\
(\%)\end{array}$ \\
\hline Rendah & 13 & 15,1 \\
sedang & 59 & 68,6 \\
Tinggi & 14 & 16,3 \\
Jumlah & 86 & 100 \\
\hline
\end{tabular}

Sumber: Data Primer Penelitian, 2018 
Tabel 4. Motivasi Terbesar yang Mendorong Penerimaan Terhadap Kartu Tani

\begin{tabular}{lc}
\hline \multicolumn{1}{c}{ Motivasi } & Rata-rata \\
\hline Kebutuhan Fisik & 3,16 \\
Kebutuhan Sosial & 3,10 \\
Kebutuhan Ekonomi & 2,92 \\
\hline
\end{tabular}

Sumber: Data Primer Penelitian, 2018

pembelajaran, petani akan memiliki akses lebih baik untuk dapat meningkatkan kemampuannya dalam menggunakan kartu tani sehingga mampu memperoleh manfaat secara maksimal dari adanya program tersebut. Hal ini sesuai dengan pendapat Sumarlan et al (2012) yang menyatakan bahwa untuk meningkatkan motivasi petani dapat dilakukan melalui pendidikan, penyuluhan maupun pelatihan yang dilakukan oleh lembaga terkait untuk meningkatkan kapasitas petani.

\section{Analisis Adopsi Petani Tanaman Padi terhadap Program Kartu Tani}

Petani memiliki pandangan dan penilaian yang beragam dengan adanya kebijakan penggunaan kartu tani sebagai alat penebus pupuk bersubsidi. Pro dan kontra dari pihak petanipun bermunculan. Kebijakan yang diharapkan bisa diadopsi dan diterapkan kepada semua petanipun masih belum sepenuhnya terwujud. Adapun tingkatan adopsi petani terhadap penggunaan kartu tani sebagai alat penebus pupuk bersubsidi dapat dilihat pada Tabel 5 .

Berdasarkan tabel tersebut, diketahui bahwa responden paling banyak berada pada tingkat adopsi sedang yaitu berjumlah 53 orang dengan persentase $61,6 \%$. Hal ini menunjukkan bahwa tingkat adopsi responden terhadap program kartu tani tergolong sedang. Hal ini dapat ditinjau dari lima tahapan adopsi yang dimulai dari sadar, tertarik, mencoba, menilai dan mengadopsi.

Tahapan-tahapan adopsi petani terhadap program kartu tani diantaranya yaitu petani sudah cukup sadar dan mengetahui mengenai adanya kebijakan program kartu tani yang bertujuan untuk mengatasi permasalahan distribusi pupuk beserta fungsi-fungsi dan manfaatnya. Petani juga cukup tertarik dengan adanya program kartu tani, ketertarikan ini ditunjukkan dari adanya usaha petani untuk hadir di acara penyuluhan dan pelatihan yang diselenggarakan dan belajar cara menggunakan kartu tani. Petani juga aktif bertanya dan mencari informasi mengenai kartu tani kepada penyuluh maupun rekan petani. Informasi-informasi mengenai kartu tani yang diperoleh petani membuat petani menilai bahwa kartu tani sebenarnya memiliki manfaat untuk kegiatan bertaninya, khususnya untuk mendapatkan pupuk bersubsidi dan informasi usaha pertaniannya yang terdata dengan jelas.

Perbedaan nilai yang diperoleh pada tahapan adopsi menunjukkan bahwa semua petani memang telah menggunakan kartu tani, tetapi tidak semua petani mengadopsi program tersebut karena suka rela dan melalui tahapan adopsi yang sesuai. Sebagian petani mengikuti kebijakan tersebut karena terpaksa, karena kebutuhan untuk mendapatkan pupuk bersubsidi, sementara ada juga petani yang menggunakan kartu tani hanya karena mengikuti kebijakan tanpa memahami program tersebut. Selain itu, nilai adopsi petani yang berbeda juga disebabkan karena adanya perbedaan aspek-aspek pendukung yang membuat petani mau mengadopsi program kartu tani.

Berdasarkan tabel tersebut, diketahui bahwa aspek yang paling mendukung adopsi petani adalah karena ketersediaan pupuk bersubsidi yang baik yaitu selalu ada persediaan saat petani membutuhkan pupuk, kemudian diikuti jumlah dan jenis pupuk yang sesuai dengan kebutuhan petani dan harga yang lebih terjangkau. Petani juga

Tabel 5. Jumlah dan Persentase Responden berdasarkan Tingkat Adopsi

\begin{tabular}{lcc}
\hline \multicolumn{1}{c}{ Adopsi } & $\begin{array}{c}\text { Jumlah } \\
\text { Petani }\end{array}$ & Persentase \\
\hline Rendah & 14 & $16,3 \%$ \\
Sedang & 53 & $61,6 \%$ \\
Tinggi & 19 & $22,1 \%$ \\
Jumlah & 86 & $100 \%$ \\
\hline
\end{tabular}

Sumber: Data Primer Penelitian, 2018 
mengharapkan mendapatkan pupuk dengan mutu baik yang bisa diperoleh tepat waktu dan sesuai dengan tempat bertani yang dimiliki.

Dalam pelaksanaannya, petani telah mencoba menggunakan kartu tani, akan tetapi penggunaan secara individu tidak berlangsung lama. Hal ini dikarenakan petani masih merasa kesulitan dalam menggunakan kartu tani baik dari segi akses maupun teknis. Penggunaan kartu tani saat ini masih berlangsung, akan tetapi untuk memberikan kemudahan kepada petani, penebusan pupuk menggunakan kartu tani dikoordinir oleh ketua kelompok tani.

Petani tanaman padi di Kabupaten Grobogan sebagian besar mampu menerima program yang dibuat oleh pemerintah, karena program kartu tani juga memberikan dampak positif terhadap produksi padi di Kabupaten Grobogan. Ketersediaan pupuk yang lebih baik setelah adanya kartu tani membuat petani dapat memenuhi kebutuhan pupuk untuk usaha taninya dengan baik, sehingga keberlangsungan produksi padi juga semakin baik. hal ini dapat dilihat dari peningkatan produksi padi di Kabupaten Grobogan sebanyak 2,5\% sejak tahun 2016, akan tetapi untuk masa yang akan datang petani belum bisa memutuskan apakah akan terus menggunakan kartu tani atau tidak. hal ini sesuai dengan pendapat Soekartawi (2005) yang menyatakan bahwa adopsi dapat diartikan sebagai suatu kegiatan berupa penerimaan, penerapan serta penggunaan sesuatu yang baru baik berupa ide atau teknologi dengan melalui beberapa tahapan

Tabel 6. Aspek Pendukung Adopsi

\begin{tabular}{lc}
\hline $\begin{array}{c}\text { Aspek Pendukung } \\
\text { Adopsi }\end{array}$ & Rata-Rata \\
\hline Ketersediaan & 3,33 \\
Jumlah & 3,32 \\
Jenis & 3,20 \\
Mutu & 3,19 \\
Harga & 3,21 \\
Waktu & 2,45 \\
Tempat & 2,13 \\
\hline
\end{tabular}

Sumber: Data Primer Penelitian, 2018 dan proses.

Upaya yang dapat dilakukan untuk meningkatkan tingkat adopsi petani selain penyuluhan dan pelatihan yaitu dengan adanya pendampingan secara berkelanjutan, sehingga petani secara rutin menggunakan teknologi baru yang akan di adopsi. Hal ini sesuai dengan Kustiari et al. (2010) menyatakan bahwa faktor yang menyebabkan kendala adopsi yaitu kurangnya pendampingan dalam penggunaaan teknologi dan petani belum terbiasa untuk melakukan transaksi yang berhubungan dengan bank.

\section{Uji Pengaruh Sikap dan MotivasiPetani terhadap Adopsi Program Kartu Tani}

Berdasarkan uji regresi linear berganda SPSS 16, diperoleh persamaan regresi sikap, motivasi dan adopsi adalah sebagai berikut.

Berdasarkan Tabel tersebut, diperoleh hasil persamaan regresi linear berganda $\mathrm{Y}=$ $10,297+0,630 \mathrm{X} 1+0,843 \mathrm{X} 2+\mathrm{e}$. Persamaan ini menunjukkan bahwa nilai konstanta adalah 10,297. Koefisien regresi variabel sikap (X1) adalah 0,630 yang artinya apabila sikap mengalami satu kenaikan, maka nilai adopsi akan naik sebesar 0,630. Koefisien regresi variabel Motivasi (X2) adalah 0,843 yang artinya apabila motivasi mengalami satu nilai kenaikan, maka nilai adopsi akan naik sebesar 0,843. Keterkaitan antara sikap dan motivasi sebagai variabel bebas dengan adopsi sebagai variabel terikat, menunjukkan bahwa variabel bebas mempengaruhi variabel terikat. Hal ini sesuai dengan pendapat Ghozali (2016) yang menyatakan bahwa uji regresi merupakakan studi yang membahan mengenai ketergantungan atau pengaruh variabel bebas dengan variabel terikat. Pengaruh sikap dan motivasi terhadap adopsi menunjukkan bahwa semakin baik respon yang diberikan petani dan semakin besar dorongan yang dimiliki petani untuk memenuhi kebutuhannya, maka penerimaan petani terhadap program kartu tani juga akan semakin baik. Hal ini karena petani akan merespon positif terhadap sesuatu yang dapat memenuhi kebutuhannya. Hal ini sesuai dengan pendapat Murtiningsih et al (2019) 
Tabel 7. Hasil Uji Pengaruh Sikap dan Motivasi Petani terhadap Adopsi Program Kartu Tani

\begin{tabular}{lcc}
\hline Model & $\begin{array}{c}\text { Unstandardized } \\
\text { Coefficients } \\
\text { B }\end{array}$ & $\begin{array}{c}\text { Standardized } \\
\text { Coefficients } \\
\text { Beta }\end{array}$ \\
\hline Constant & 10,297 & \\
Sikap & 0,630 & 0,458 \\
Motivasi & 0,843 & 0,514 \\
\hline
\end{tabular}

yang menytakan bahwa peningkatan sikap dan motivasi berbanding lurus dengan meningkatnya adopsi.

\section{Uji Pengaruh Variabel Sikap dan Variabel Motivasi terhadap Variabel Adopsi Secara Serempak}

Berdasarkan uji yang telah dilakukan, diketahui nilai sig. $\mathrm{F}$ adalah 0,000 . Nilai tersebut kurang dari 0,05 yang artinya $\mathrm{Ha}$ diterima dan $\mathrm{H} 0$ ditolak, maka ada pengaruh dari variabel sikap dan variabel motivasi sebagai variabel bebas secara serempak terhadap variabel adopsi sebagai variabel terikat. Hal ini sesuai dengan pendapat Ghozali (2016) yang menyatakan bahwa dalam uji F, Ha diterima jika nilai Sig. $\leq 0,05$ yang artinya ada pengaruh dari variabel bebas secara serempak terhadap variabel terikat dan $\mathrm{H} 0$ diterima jika nilai sig. $>0,05$ yang artinya tidak ada pengaruh dari variabel bebas secara serempak terhadap variabel terikat.

Variabel sikap dan motivasi berpengaruh terhadap variabel adopsi program kartu tani secara serempak karena ketika petani memiliki pengetahuan mengenai tujuan, manfaat dan cara menggunakan kartu tani, merasakan bahwa kartu tani memiliki banyak manfaat untuk kegiatan bertaninya serta mau melakukan tindakan untuk menggunakan kartu tani, kemudian didukung dengan adanya dotongan dari aspek kebutuhan, social dan ekonomi sehingga petani mau mengadopsi program kartu tani. Hal ini menunjukkan bahwa apabila tingkat sikap dan motivasi petani tinggi, maka tingkat adopsi petani juga tinggi, begitu pula sebaliknya. Hal ini sesuai dengan pendapat Kusumaningrum (2012) yang menyatakan bahwa apabila tingkat motivasi meningkat maka tingkat adopsi juga akan meningkat. Hal ini diperkuat oleh pendapat pendapat Suandi et al. (2013) yang menyatakan bahwa semakin tinggi tingkat sikap petani maka tingkat penerapan suatu teknologi pertanian juga akan tinggi.

\section{Uji Pengaruh Variabel Sikap dan Variabel Motivasi terhadap Variabel Adopsi Secara Parsial}

Berdasarkan Uji t yang telah dilakukan dengan menggunakan SPSS 16, untuk menganalisis pengaruh sikap dan motivasi terhadap adopsi program kartu tani diperoleh hasil sebagai berikut :

Berdasarkan Tabel tersebut, diperoleh nilai $\mathrm{t}$ hitung variabel sikap adalah 6,710 dengan nilai Sig. 0,000 , sedangkan nilai $\mathrm{t}$ tabel dari df $=83$ adalah 1,98896, maka $t$ hitung lebih besar dari $t$ tabel dan nilai Sig lebih kecil dari 0,05 yang artinya variabel sikap (X1) berpengaruh secara parsial terhadap variabel adopsi (Y). Nilai t hitung variabel motivasi adalah 7,532 dengan nilai Sig. 0,000, sedangkan nilai $\mathrm{t}$ tabel dari $\mathrm{df}=83$ adalah 1,98896, maka t hitung lebih besar dari $\mathrm{t}$ tabel dan nilai Sig lebih kecil dari 0,05 yang artinya variabel motivasi (X2) berpengaruh secara parsial terhadap variabel adopsi (Y). hal ini sesuai dengan pendapat Ghozali (2016) yang menyatakan bahwa Dalam uji t Ho ditolak jika nilai $\mathrm{t}$ hitung $>\mathrm{t}$ tabel dan Ho ditolak jika nilai Sig. $\leq 0,05$ begitu pula sebaliknya, maka ada pengaruh dari variabel bebas secara parsial terhadap variabel terikat, begitu pula sebaliknya.

Variabel sikap (X1) berpengaruh secara parsial terhadap variabel adopsi (Y) karena ketika petani memiliki pengetahuan mengenai tujuan, manfaat dan cara menggunakan kartu

Tabel 8. Hasil Uji Pengaruh Variabel Sikap danVariabel Motivasi terhadap Variabel Adopsi Secara Parsial

\begin{tabular}{lcc}
\hline & $\mathrm{T}$ & Sig. \\
\hline (Constant) & 2,429 & 0,017 \\
Jumlah Sikap & 6,710 & 0,000 \\
Jumlah Motivasi & 7,532 & 0.000 \\
\hline
\end{tabular}


tani, petani merasakan bahwa kartu tani memiliki manfaat untuk kegiatan bertaninya serta mau melakukan tindakan untuk menggunakan kartu tani, maka secara mau atau tidak mau petani akan menerima atau mengadopsi adanya program kartu tani. Hal ini sesuai dengan Robbins dan Judge (2007) yang menyatakan bahwa sikap merupakan bentuk interaksi dari komponen kognitif (pengetahuan), afektif (perasaan) dan konatif (kecenderungan bertindak) agar dapat memahami serta merasakan dan berperilaku terhadap sesuatu. Hal ini diperkuat dengan pendapat Kusumaningrum (2012) yang menyatakan bahwa apabila tingkat motivasi meningkat maka tingkat adopsi juga akan meningkat.

Variabel motivasi (X2) berpengaruh terhadap variabel adopsi (Y) karena motivasi petani adalah suatu hal yang mendorong petani untuk memiliki kemauan melakukan suatu kegiatan, sehingga tinggi dan rendahnya motivasi petani akan mempengaruhi kemauan petani untuk mengadopsi program kartu tani. Petani memiliki dorongan dari segi kebutuhan yaitu kebutuhan untuk mendapatkan pupuk, dari segi sosial karena secara kelompok telah diberi tanggungjawab oleh pemerintah dan dari segi ekonomi yang lebih menguntungkan, sehingga petani mau mengadopsi kartu tani. Hal ini sesuai dengan pendapat Kusumaningrum (2012) yang menyatakan bahwa apabila tingkat motivasi meningkat maka tingkat adopsi juga akan meningkat.

Motivasi petani tanaman padi di Kabupaten Grobogan tergolong sedang, hal ini disebabkan karena walaupun sudah memiliki dorongan untuk menggunakan kartu tani, tetapi petani seringkali masih kesulitan untuk menggunakan kartu tani, sehingga untuk meningkatkan motivasi petani diperlukan adanya kerjasama antara penyuluh dan tokoh petani supaya dapat memberikan pembinaan berkelanjutan, sehingga petani akan terbiasa menggunakan kartu tani. Hal ini sesuai dengan pendapat Ruhimat (2015) yang menyatakan bahwa usaha yang dapat dilakukan untuk meningkatkan motivasi petani yaitu dengan melakukan pendidikan, pelatihan, penyuluhan dan pendampingan.

\section{SIMPULAN DAN SARAN}

\section{Simpulan}

Berdasarkan penelitian pengaruh sikap dan motivasi petani tanaman padi terhadap program kartu tani pada kelompok tani di Kabupaten Grobogan, disimpulkan bahwa ada pengaruh dari sikap dan motivasi terhadap adopsi program kartu tani baik secara serempak maupun parsial. Sikap dan motivasi berbanding lurus dengan adopsi, semakin baik sikap petani dan semakin besar motivasi yang mendorong petani maka adopsi petani terhadap suatu program juga semakin baik. sikap, motivasi dan adopsi petani terhadap program kartu tani secara berturut-turut tergolong sedang. Hal ini dikarenakan meskipun petani sudah melaksanakan program kartu tani tetapi masih merasa belum terlalu mengerti mengenai penggunaan kartu tani karena tidak melalui proses tahapan adopsi sebagaimana mestinya. Hal ini juga disebabkan karena adanya perbedaan aspek pendukung yang membuat petani mau mengadopsi program.

\section{Saran}

Sikap, motivasi dan adopsi petani dapat ditingkatkan dengan melakukan penyuluhan, pelatihan, pembinaan serta pendampingan secara berkelanjutan terkait program kartu tani. Pelaksanaannya bisa dilakukan dengan kerjasama antara penyuluh dengan pengurus kelompok tani dan tokoh masyarakat setempat, sehingga petani tidak perlu menunggu penyuluh untuk belajar, melainkan dapat saling berbagi pengetahuan dengan rekan sesama petaninya secara mandiri dan menyeluruh. Pihak perbankan juga bisa diikutsertakan dalam pelatihan penggunaan alat EDC dan menambah jumlah alat, guna mempermudah akses penebusan pupuk bersubsidi sehingga dapat dijangkau seluruh petani 


\section{DAFTAR PUSTAKA}

Akbar, S.P. dan H. Usman. 2006. Metode Penelitian Sosial. Jakarta. Bumi Aksara.

Azwar, S. 2007. Sikap Manusia Teori \& Pengukurannya, edisi 2. Yogyakarta. Pustaka Pelajar.

Azwar, S. 2010. Dasar-dasar psikometri. Yogyakarta. Pustaka Pelajar.

Ban, A.V.D dan H.S. Hawkins. 1999. Penyuluh pertanian. Yogyakarta.

BPS. 2017. Kabupaten Grobogan Dalam Angka 2017. Badan Pusat Statistik

Biro Infrastruktur dan Sumber Daya Alam Provinsi Jawa Tengah. 2016. Petunjuk Praktis Penggunaan Kartu Tani Melalui Sistem Informasi Pertanian Indonesia (SINPI) Di Jawa Tengah.

http://www.biroinfrasda.jatengprov.go.id. Diakses Senin 26 November 2018.

Burhansyah, R. 2014. Faktor-faktor yang mempengaruhi adopsi inovasi pertanian pada gapoktan di Kalimantan Barat (studi kasus : Kabupaten Pontianak dan Landak). J. Informatika pertanian 23(1): 65-74

Dantes, N. 2012. Metode Penelitian. Yogyakarta. Andi Offset.

Dayakisni, T. dan Hudaniah. 2003. Psikologi sosial. Universitas Muhammadiyah Malang, Malang.

Denny, R. 1997. Sukses Memotivasi (jurus jitu meningkatkan prestasi), terj. Pius M, Sumaktoyo. Jakarta. PT. Gramedia Pustaka Utama.

Fachrista, I.A. dan M. Sarwendah. 2014. Persepsi dan tingkat adopsi petani terhadap inovasi teknologi pengelolaan tanaman terpadu padi sawah. J. Agronomika 3(1): 1-9.

Ferdinand, A. 2006. Metode Penelitian Manajemen: Pedoman Penelitian untuk skripsi, Tesis dan Disertai Ilmu Manajemen. Universitas Diponegoro, Semarang.

Gerungan, W. A. 2004. Psikologi Sosial. Bandung. PT Refika Aditama.

Ghozali, I. 2012. Aplikasi Analisis Multivariate Dengan Program IBM SPSS 20. Badan Peneliti Universitas Diponegoro, Semarang.

Ghozali, I. 2016. Aplikasi Analisis Multivariate Dengan Program IBM SPSS 23. Badan Penerbit Universitas Diponegoro, Semarang.

Gibson, J. L., Ivancevich dan Donnely. 1997. Organisasi dan Manajemen, Perilaku Stuktur Proses, Erlangga,Jakarta, Alih Bahasa : Ir. Hunuk Addiarni, M.M. Jakarta. Bina Rupa Aksara

Ginting, M. 2002. Strategi Komunikasi Bagi Para Penyuluh dalam Pembangunan Masyarakat Desa. FP USU, Medan.

Haris, W.A., M. Sarma dan A.F. Falatehan. 2017. Analisis peranan subsektor tanaman pangan terhadap perekonomian Jawa Barat. Journal of Regional and Rural Development Planning 1(3): 231-242

Janti, S. 2014. Analisis validitas dan reliabilitas dengan skala likert terhadap pengembangan SI/TI dalam penentuan pengambilan keputusan penerapan strategic planning pada industri garmen. Prosiding. Seminar Nasional Aplikasi Sains \& Teknologi (SNAST). Yogyakarta.

Jorgi, R. 2018. Hubungan pengetahuan petani 
dengan efektivitas pelaksanaan program kartu tani di Kabupaten Semarang. Skripsi. Fakultas Peternakan dan Pertanian Universitas Diponegoro.

Kurniawati, E. 2018. Persepsi masyarakat terhadap penggunaan kartu tani di Kabupaten Pati (kasus Desa Wotan dan Desa Pakem, Kecamatan Sukolilo). Skripsi. Fakultas Geografi Universitas Gajah Mada.

Kustiari, R., H.P Salim., S. Pasaribu, B. Sayaka, dan E. Surya. 2010. Akselerasi Sistem Inovasi Inovasi Pengolahan Hasil dan Alsintan Dalam Rangka Mendukung Ketahanan Pangan. Laporan APBN Pusat Analisis Sosial Ekonomi dan Kebijakan Pertanian. $10 \mathrm{hlm}$.

Kusumaningrum, A. 2012. Faktor-Faktor yang Mempengaruhi Penerapan Budidaya Tanaman Padi Secara Modern dan Tradisional di Kecamatan Bayan Kabupaten Purworejo. Skripsi. Fakultas Pertanian Universitas Gajah Mada. .

Malhotra, Naresh K. 2006. Riset Pemasaran : Pendekatan Terapan Jilid 2. Jakarta. PT. Indeks

Moekijat. 1990. Pengembangan dan Motivasi. Bandung. Pionir Jaya

Moko, K. W., Suwarto dan B. W. Utami. 2017. Presepsi petani terhadap program kartu tani di Kecamatan Kaijambe Kabupaten Sragen. J. Caraka Tani 32(1) : $10-14$

Peraturan Presiden nomor 15. 2011. Penetapan Pupuk Bersubsidi. Presiden Republik Indonesia, Jakarta.

Petunjuk Teknis Kartu Tani Jawa Tengah. 2016. Petunjuk Teknis Kartu Tani
Melalui Sistem Informasi Manajemen Pangan Indonesia. Semarang. Sekertaris Daerah Provinsi Jawa Tengah

Priyanto, D. 2010. Paham Analisis Statistika Data dengan SPSS. Yogyakarta. Media Kom

Putra, S.A.W., S.S. Hariadi dan Harsoyo. 2012. Pengaruh peran penyuluh dan kearifan local terhadap adopsi inovasi padi sawah di Kecamatan Montasik Kabupaten Aceh Besar. Kanal 1(1): 1101.

Rahmawati, F. dan M.A. Sunito. 2013. Faktor-faktor yang mempengaruhi akses dan control laki-laki dan perempuan dalam pengelolaan sumberdaya hutan rakyat (studi: Desa Gunung Bunder II, Kecamatan Pamijahan, Kabupaten Bogor, Provinsi Jawa Barat). J. Sosiologi Pedesaan 1(03): 206-221.

Robbins, S. P dan Judge. 2007. Perilaku Organisasi. Jakarta. Salemba Empat

Ruhimat, I. S. 2015. Tingkat motivasi petani dalam penerapan sistem agroforestry. J. Pertanian Sosial dan Ekonomi Kehutanan 12(2): 1-11.

Rusastra, I W., B. Sayaka, dan Saptana. 2002. Kebijakan harga dan subsidi faktor produksi. Dalam T. Sudaryanto,I W. Rusastra, A. Syam, dan M. Ariani(Ed.). Analisis Kebijakan: Paradigma pembangunan dan kebijakan pengembangan agro industri. Monograph Series No. 21. Pusat Penelitian dan Pengembangan Sosial Ekonomi Pertanian, Bogor.

Sani, A dan Mahsyhuri, M. 2010. Metodologi Riset Manajemen Sumber Daya Manusia. Cetakan Pertama. Maliki Press. UIN, Malang. 
Santoso, S. 2010. Statistik Nonparametrik. Jakarta. Elex Media Komputindo

Singgih, S. 2000. Buku Latihan SPSS Statistik Parametik. Jakarta. PT. Elex Media Komputindo Gramedia

Sitanggang, L., S. N. Lubis dan S. I. Kusuma. 2014. Tingkat adopsi petani terhadap penggunaan pupuk sesuai dosis anjuran pada usahatani padi sawah (Studi Kasus: Desa Sidoarjo Dua Ramunia, Kecamatan Beringin, Kabupaten Deli Serdang). USU, Medan.

Suandi, R. Siata dan I. Sardi. 2013. Sikap petani terhadap program pencetakan sawah baru di Kelurahan Simpang Kecamatan Berbak Kabupaten Tanjung Jabung Timur. J. sosio ekonomika bisnis. 16(2): 45-52.

Sugiyono. 2001. Metode Penelitian Administrasi. Bandung. Alfabeta.

Sugiyono, 2015. Metode Penelitian Kombinasi (Mix Methods). Bandung. Alfabeta.

Sumarlan., Sumardjo., T. Prabowo dan S.G. Darwis. 2012. Peningkatan kinerja petani sekitar hutan dalam penerapan sistem agroforestri di pegunungan Kendeng Pati. J. Agroekonomi 30(1): 25-39.

Soekartawi. 2005. Prinsip Dasar Komunikasi Pertanian. UI Press. Jakarta.

Uno, H. 2007. Teori Motivasi dan Pengukurannya (Analisis di bidang pendidikan). Jakarta. Bumi Aksara.

Winardi, J. 2004. Motivasi dan Pemotivasian Dalam Manajemen. Cetakan Ketiga. Jakarta. Raja Grafindo Persada. 